\title{
Actuation Dosing Unit
}

National Cancer Institute

\section{Source}

National Cancer Institute. Actuation Dosing Unit. NCI Thesaurus. Code C122629.

A dosing unit equal to the amount of active ing redient(s) contained in an actuation. 